\title{
PENGEMBANGAN E-MODUL MENGGUNAKAN 3D PAGEFLIP PROFESSIONAL PADA MATERI MOMENTUM DAN IMPULS SMA/MA KELAS XI
}

Hammiyati Fitri ${ }^{1}$, Maison ${ }^{2}$, dan Dwi Agus Kurniawan ${ }^{3}$

1,2,3 Program Studi Pendidikan Fisika FKIP Universitas Jambi, Jambi, Indonesia

Email: hammiyatif@gmail.com

\section{Info Artikel}

Diterima:

8 Oktober 2018

Disetujui:

3 Maret 2019

Dipublikasikan:

30 Juni 2019

\begin{abstract}
Abstrak:
Penelitian ini bertujuan untuk mengembangkan e-modul pada materi momentum dan impuls dan mengetahui persepsi siswa. Penelitian ini merupakan penelitian dan pengembangan yang menggunakan model Borg dan Gall. Tahapan penelitian meliputi potensi dan masalah, pengumpulan data, desain produk, validasi desain, revisi desain, ujicoba produk, revisi produk dan produk akhir. Subjek uji coba penelitian ini adalah siswa kelas XI IPA SMA N 11 Muaro Jambi. Instrumen yang digunakan adalah angket validasi media dan materi serta angket persepsi siswa. Data dianalisis secara deskriptif. E-modul yang dikembangkan tediri dari cover modul, peta kedudukan modul, kegiatan pembelajaran per sub bab dengan contoh dan latihan soal serta tes formatif akhir, memuat materi, video, animasi, simulasi. Hasil validasi ahli media dan materi masing-masing sebesar 3.68 dan 3.1 dengan kategori baik. Hasil analisis persepsi siswa diperoleh skor rata-rata indikator keseluruhan adalah 3.45 yang dikategorikan baik.
\end{abstract}

Kata kunci: Modul Elektronik, Momentum dan Impuls

\begin{abstract}
:
This research aims to develop e-modules on the materials of momentum and impulses and know the perception of students. This research is a research and development that uses the Borg and Gall models. The stages of research include potential and problems, data collection, product design, design validation, design revisions, product testing, product and final product revisions. The test subject of this research is XI IPA High school students $N 11$ Muaro Jambi. The instrument used is a media and material validation poll and a student perception questionnaire. Data is analyzed descriptively. E-modules are developed from the module cover, the map of the position of the module, the learning activities per subchapter with examples and exercises and the final formative tests, load materials, videos, animations, simulations. The validation results of media experts and material respectively at 3.68 and 3.1 in good category. The results of the students ' perception analysis obtained an average score overall indicator is 3.45 which is categorized well.
\end{abstract}

Keywords: Electronic modules, momentum and impulses 


\section{Pendahuluan}

Fisika merupakan salah satu bagian dari ilmu sains, belajar Fisika bukan hanya sekedar tahu matematika, tetapi lebih jauh siswa diharapkan mampu memecahkan masalah-masalah yang dihadapi dalam kehidupan sehari-hari. Fisika tidak hanya berisi tentang pengetahuan untuk dihafal, akan tetapi fisika membentuk proses pengetahuan dan penguasaan konsep di benak siswa dalam proses belajar mengajar. Pembelajaran fisika di sekolah menengah hendaknya menekankan pada aktivitas siswa, Masril (2012:3) mengemukakan dalam pengajaran Fisika perlu kecermatan bagaimana memandu para siswa dalam pembelajaran dari pengetahuan prapembelajaran yang dimiliki mereka.

Fisika merupakan ilmu pengetahuan yang sangat fundamental, hal ini dikarenakan Fisika berperan penting dalam perkembangan teknologi. Perkembangan teknologi tersebut tidak terlepas dari konsep-konsep Fisika. Salah satu konsep yang turut andil dalam perkembangan teknologi adalah konsepkonsep yang ada pada materi Momentum dan Impuls. Momentum dan Impuls merupakan mata pelajaran semester ganjil di tingkat SMA dengan alokasi waktu $2 \times 45$ menit dengan 2 kali pertemuan tatap muka. Adapun pokok bahasan yang dibahas dalam mata pelajaran ini meliputi Konsep Impuls, konsep momentum, hubungan Impuls dan Momentum, hukum kekekalan Momentum, dan Tumbukan.

Berdasarkan wawancara peneliti pada salah satu guru Fisika kelas XI IPA di SMA N 11 Muaro Jambi dapat diketahui bahwa hambatan yang ditemui saat pembelajaran fisika adalah siswa kurang tertarik belajar fisika, kemudian siswa mengalami kesulitan dalam menerima materi, salah satunya materi Momentum dan Impuls, pada materi ini banyak penerapannya dalam kehidupan sehari-hari, namun bahan ajar yang ada sekarang belum memuat penerapan tersebut dan juga kurang cukup membuat siswa belajar secara mandiri. Bahan ajar utama yaitu satu buku paket dan satu LKS, guru masih membutuhkan bahan ajar lain yang menarik dan mudah dipahami untuk menunjang proses belajar mengajar. Belum adanya modul, baik yang dibeli maupun yang dikembangkan oleh guru, guru jarang menggunakan media TIK dalam proses belajar mengajar, sedangkan media TIK berguna dalam proses belajar siswa untuk memahami materi yang akan dipelajari siswa. Bahan ajar yang guru inginkan adalah berupa elektronik. Dan dari hasil wawancara terhadap siswa kelas XI IPA di SMA Negeri 11 Muaro Jambi dapat diketahui bahan ajar yang digunakan belum cukup membantu penguasaan konsep pada mata pelajaran fisika, selain itu penjelasan guru di sekolah belum cukup untuk memahami materi yang terdapat dalam pembelajaran fisika, karena keterbatasan waktu. Sehingga siswa masih membutuhkan bahan ajar lain yang menarik dan mudah dipahami untuk dapat belajar secara mandiri.Siswa tertarik dengan bahan ajar yang berbentuk elektronik yang didalamnya memuat materi, animasi, kuis dan gambar.

Berdasarkan hasil observasi di SMA N 11 Muaro Jambi, di peroleh informasi bahwa kurikulum yang diterapkan adalah KTSP. Bahan ajar yang digunakan siswa terbatas, dan kurang cukup untuk membuat siswa belajar secara mandiri, bahan ajar cetak tersebut hanya berisi ringkasan materi, gambar, contoh soal dan latihan- latihan soal. Pembelajaran masih berpusat pada guru, di mana siswa hanya mendengarkan, mengerjakan soal, dan mengerjakan tugas.

Untuk mengatasi permasalahan ini, maka perlu dilakukan inovasi pembelajaran dengan mengembangkan bahan ajar yang lebih mudah untuk di pahami siswa serta memiliki tampilan yang menarik. Hal ini diharapkan agar dapat meningkatkan pemahaman siswa terhadap materi yang diajarkan serta siswa dapat belajar secara mandiri. Salah satu bahan ajar yang saat ini tengah berkembang adalah modul, Daryanto (2013:31) mengemukakan bahwa Modul merupakan sebuah bahan ajar yang tersusun sedemikian rupa dan disajikan dalam bentuk tertulis sehingga siswa dapat belajar secara mandiri. Untuk menghasilkan modul yang mampu meningkatkan minat siswa dalam proses pembelajaran maka perlu memperhatikan karakteristik dan prosedur penyusunan modul yang benar. Daryanto (2013:9) menyebutkan lima karakteristik pengembangan suatu modul agar dapat memotivasi siswa untuk belajar secara mandiri adalah self instrudaction, self 
contained, stand alone, adaptive, dan use friendly.

Kemajuan teknologi informasi dan komunikasi memungkinkan modul dapat dibuat dalam sajian elektronik yang disebut modul elektronik, Suarsana (2013:266) menyatakan bahwa, E-modul merupakan suatu modul yang dapat menampilkan gambar, vidio, audio, foto, animasi, kuis yang bersifat interaktif sehingga tercipta pembelajaran yang aktif . sedangkan menurut Sugianto(2013:110) Modul elektronik adalah sebuah bentuk penyajian bahan belajar mandiri yang disusun secara sistematis ke dalam unit pembelajaran terkecil untuk mencapai tujuan pembelajaran tertentu yang disajikan ke dalam format elektronik yang di dalamnya terdapat animasi, audio, navigasi yang membuat pengguna lebih interaktif dengan program.

Menurut Ghaliyah (2015:149) modul elektronik adalah modul yang ditransformasikan penyajiannya ke dalam bentuk elektronik. Selanjutnya menurut Wahyuni (2013:40) modul elektronik fisika adalah suatu paket pembelajaran yang memuat satu unit konsep dari bahan pelajaran fisika yang ditampilkan dengan menggunakan piranti elektronik berupa komputer. Sehubungan dengan hal tersebut Wiyoko (2014:11) mengatakan bahwa Kegiatan belajar mengajar dengan melibatkan teknologi untuk mengemas materi yang akan diajarkan dapat menciptakan pembelajaran yang optimal. Software yang digunakan untuk menghasilkan modul elektronik adalah $3 D$ PageFlip Professional, $3 D$ PageFlip Professional adalah suatu software yang dapat dimanfaatkan untuk membuat bahan ajar dengan efek 3D. Aplikasi ini mampu menjadikan tampilan modul elektronik menjadi lebih menarik dengan tambahan animasi, gambar, vidio, audio-visual, berbagai format seperti Exe, Zip, Html, 3DP, screen Saver dan lain-lain. Aplikasi $3 D$ PageFlip Professional ini juga menyediakan pengaturan seperti magazine, dokumen dan sebagainya.

Menurut Amalia (2015:25) 3D

PageFlip Professional adalah suatu software yang dapat dimanfaatkan untuk membuat bahan ajar berbentuk ebook digital dengan efek 3D. Selanjutnya Salsabila (2013:12) menyebutkan bahwa $3 D$ PageFlip Professional merupakan salah satu jenis perangkat lunak komputer yang dapat membuat tampilan animasi sehingga mampu menciptakan media pembelajaran interaktif bagi siswa.

Berdasarkan gagasan tersebut, Penelitian ini memilih bahan ajar karena bahan ajar yang digunakan belum cukup untuk membuat siswa belajar secara mandiri, sehingga perlu adanya pengembangan bahan ajar untuk memfasilitasi siswa belajar secara mandiri. Peneliti bermaksud untuk mengembangkan modul elektronik yang didalamnya terdapat berbagai unsur diantaranya teks, video, gambar, foto, animasi, audio-visual yang disusun dalam bentuk modul Elektronik menggunakan Aplikasi 3D PageFlip Professional sebagai pedoman siswa yang nantinya diharapkan dapat menambah variasi bahan ajar di SMAN 11 Muaro Jambi dan menambah minat siswa dalam mengikuti kegiatan belajar mengajar di kelas sehingga diharapkan siswa dapat memaksimalkan penggunaan TIK sebagai sumber belajar serta dengan penyediaan modul elektronik diharapkan dapat memberikan mamfaat dalam proses pembelajaran Fisika baik, bagi guru maupun siswa. Berdasarkan gagasan dan inovasi tersebut, peneliti bermaksud melakukan penelitian tentang "Pengembangan Modul Elektronik menggunakan Aplikasi $3 D$ PageFlip Profesional pada materi Momentum dan Impuls kelas XI SMA"

Pengembangan modul elektronik juga pernah dilakukan oleh Wiyoko (2014:11) dengan judul "Mengembangkan media pembelajaran modul elektronik animasi interaktif untuk kelas XI SMA di tinjau dari motivasi belajar siswa" dalam penelitiannya memberikan saran yakni diharapkan pada peneliti selanjutnya dapat mengembangkan isi modul yang diujicobakan tidak hanya satu kegiatan pembelajaran untuk mewakili proses pembelajaran serta dapat membuat modul elektronik pada materi pembelajaran fisika yang lain.

Penelitian ini bertujuan untuk mengembangkan modul elektronik fisika sebagai penunjang pembelajaran fisika pokok bahasan Momentum dan Impuls dan untuk mengetahui persepsi siswa terhadap modul elektronik tersebut. Adapun manfaat dari pengembangan yaitu dapat digunakan sebagai 
salah satu sumber belajar yang dapat memotivasi siswa dalam belajar fisika dan dapat digunakan sebagai media pembelajaran mandiri bagi siswa.

\section{Metode Penelitian}

Jenis Penelitian

Penelitian ini tergolong penelitian dan pengembangan atau Research and Development (R\&D), dapat diartikan sebagai suatu proses atau langkah-langkah untuk mengembangkan suatu produk baru atau menyempurnakan produk yang telah ada. Ada beberapa model penelitian pengembangan dalam bidang pendidikan antara lain model Sugiyono, model Borg and Gall, dan lain-lain. Dalam penilitian ini model pengembangan yang digunakan penulis adalah model Borg and Gall yang telah disederhanakan oleh sugiyono.

Waktu dan Tempat Penelitian

Penelitian dilaksanakan di SMA N 11 Muaro Jambi pada tanggal 8 Februari 2017.

Subjek Penelitian

Subjek penelitian ini terdiri dari siswa kelas XI IPA di SMAN 11 Muaro Jambi. Penelitian di kelas XI IPA yaitu untuk melihat persepsi siswa terhadap modul elektronik, sedangkan di kelas XII IPA yaitu untuk reliabilitas angket.

Prosedur Pengembangan

Adapun langkah-langkah dalam penelitian pengembangan menggunakan metode Borg and Gall yang dikemukakan oleh Sugiyono, namun peneliti hanya menggunakan metode sampai tahap revisi, dikarenakan mengingat waktu pelaksananya.

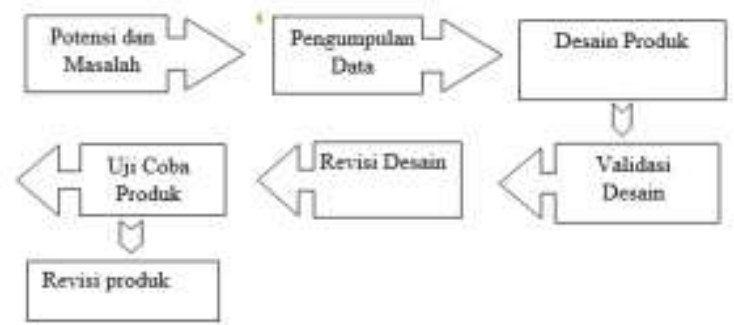

Gambar 2. Tahap Pengembangan Model Borg and Gall berdasarkan Modifikasi dari menurut Sugiyono (2014)
Berdasarkan gambar diatas dapat diberikan penjelasan sebagai beikut:

1. Potensi dan masalah Tahapan mengenai potensi atau masalah adalaha sebagai berikut:

a. Analisis kebutuhan dilakukan dengan cara wawancara. Wawancara yang dilakukan terhadap siswa SMA kelas XI untuk menemukan masalah yang dihadapi selama pembelajaran.

b. Kajian pustaka dilakukan dengan mengkaji literatur penelitian dan sumber pendukung untuk penelitian. Literatur penelitian dapat berupa penelitian terdahulu, buku Fisika, bahan ajar cetak yang telah dikembangkan, dan sebagainya.

\section{Mengumpulkan informasi}

Setelah mendapatkan potensi dan masalah yang ada, maka diperlukan pengumpulan informasi yang dapat digunakan sebagai bahan untuk perencanaan produk yang diharapkan dapat mengatasi masalah dan menggali potensi yang dimiliki mahasiswa. Tahapan ini meliputi perencanaan tujuan produk, target dari penggunaan produk, dan penjelasan penggunaan produk.

\section{Desain produk}

Berbagai informasi dan perencanaan yang telah dilakukan sebelumnya, dituangkan ke dalam desain dan pembuatan produk yang akan digunakan. Tahap ini merupakan tahapan untuk menciptakan bentuk awal dari produk emodul yang akan dikembangkan. Desain awal ini yang nantinya dapat divalidasi dan diujicoba.

Adapun storyboard modul elektronik yang dibuat adalah sebagai berikut: 
A. Desain awal cover modul

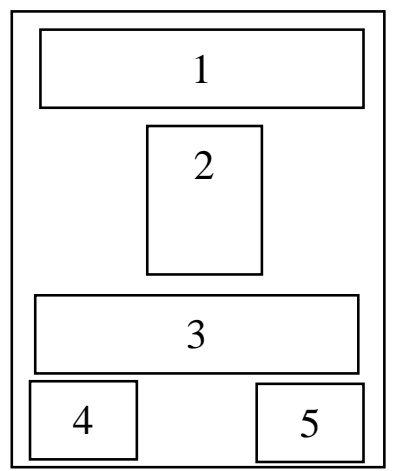

B. Tampilan pendahuluan materi

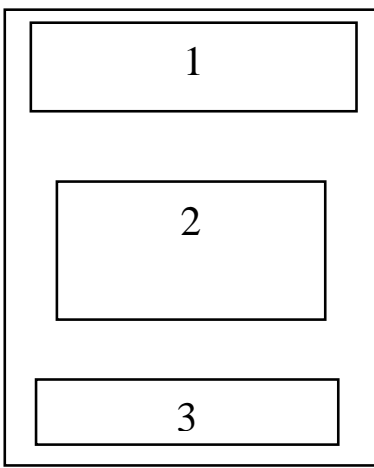

C. Tampilan awal uraian materi, rangkuman

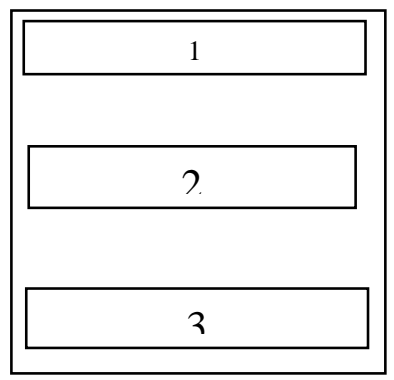

4. Validasi desain

Validasi produk e-modul dapat dilakukan dengan cara menghadirkan beberapa pakar atau tenaga ahli yang sudah berpengalaman untuk menilai produk baru yang dirancang tersebut. Validasi yang dilakukan oleh validator media dan materi. Desain produk yang telah dibuat dicermati, dinilai dan dievaluasi oleh pakar.

5. Perbaikan desain

Langkah selanjutnya setelah validasi selesai dilakukan adalah melakukan perbaikan e-modul sesuai dengan saran/masukan dari validator dan selanjutnya divalidasi lagi. Revisi terus dilakukan hingga tidak ada perbaikan yang disarankan oleh validator, sehingga ini berarti e-modul telah dapat digunakan.
6. Uji coba produk

Setelah desain produk mengalami validasi dan revisi, produk tersebut dapat dibuat menjadi bentuk awal yang akan diujicoba, atau biasa disebut prototipe. Salah satu bentuk pengujian dapat dilakukan dengan pengambilan data persepsi mahasiswa untuk mengetahui bagaimana tanggapan mahasiswa terhadap media yang dikembangkan.

7. Revisi produk dan produk akhir

Hasil dari pengujian e-modul pada mahasiswa di tahap sebelumnya, menentukan hal apa saja yang perlu direvisi dari produk. Revisi dilakukan jika ujicoba yang dilakukan sebelumnya menemukan kekurangan, salah satunya jika hasil pengujian e-modul kurang memenuhi tujuan utama dari pembuatan emodul. Setelah dilakukan revisi, maka produk dapat dibuat bentuk akhirnya yang dapat digunakan siswa.

Jenis Data

Jenis data yang digunakan pada penelitian pengembangan ini bersifat kualitatif dan kuantitatif. Data kualitatif yang diambil adalah saran dari tim validasi ahli, sedangkan data kuantitatif yang diambil adalah anket validasi ahli dan angket persepsi siswa. Data yang diperoleh dari hasil pengembangan produk ini digunakan sebagai dasar dalam menetapkan kelayakan modul elektronik ini.

\section{Instrumen Pengumpulan Data}

Adapun instrumen pengumpulan data yang digunakan antara lain.

\section{Observasi}

Observasi biasa diartikan sebagai pengamatan dan pencatatan secara sistematik terhadap unsur-unsur yang nampak dalam suatu gejala pada objek penelitian (Widoyoko, 2016). Metode observasi ini digunakan untuk melihat dan mengamati secara langsung keadaan di lapangan agar memperoleh gambaran yang lebih luas tentang permasalahan yang akan dilakukan.

\section{Telaah Dokumen}

Metode ini merupakan suatu cara pengumpulan data yang dilakukan dengan menganalisis isi dokumen yang berhubungan dengan masalah yang diteliti (Widoyoko,2016). Metode ini digunakan untuk mengumpulkan data yang telah tersedia 
dalam catatan dokumen seperti silabus, rpp, dan bahan ajar yang digunakan oelh guru mata pelajaran fisika di SMA 11 Muaro Jambi.

3. Angket Kebutuhan siswa

Pada angket kebutuhan siswa berisikan tentang aspek-aspek yang berhubungan dengan keadaan pembelajaran fisika serta halhal yang dibutuhkan dalam pembelajaran fisika.

4. Angket Validasi Ahli Media

Pada angket validasi ahli media berisikan tentang aspek-aspek yang berhubungan dengan media yang telah dikembangkan meliputi desain sampul modul, desain isi modul, desain software modul, komponen penyajian, dan kemudahan pengoperasian.

\section{Angket Validasi Ahli Materi}

Pada angket validasi ahli materi berisikan tentang aspek-aspek yang berhubungan dengan materi modul elektronik meliputi kesesuaian materi dengan tujuan pembelajaran, ketepatan materi dan isi, dan komponen kebahasaan.

6. Angket Persepsi siswa

Pada angket persepsi siswa berisikan tentang aspek-aspek yang berhubungan dengan modul elektronik yang telah dikembangkan meliputi desain sampul modul, desain isi modul, desain software modul, komponen penyajian, kemudahan pengoperasian, dan komponen kebahasaan.

Analisis Instrumen Penelitian

1. Analisis validitas

Validitas adalah keadaan yang menggambarkan tingkat instrumen yang bersangkutan mampu mengukur apa yang akan diukur. Untuk menguji validitas instrumen penelitian digunakan korelasi produk moment atau metode Pearson, dengan rumus sebagai berikut (Arikunto, 2013).

$$
r_{x y}=\frac{N \sum x y-\left(\sum x\right)\left(\sum y\right)}{\sqrt{\left\{N \sum x^{2}-\left(\sum x\right)^{2}\right\}\left\{N \sum y^{2}-\left(\sum y\right)^{2}\right\}}}
$$

Keterangan:

$r_{x y} \quad=$ koefisien korelasi antara $\mathrm{x}$ dan $\mathrm{y}$

$N \quad=$ jumlah subjek

$\Sigma x y=$ jumlah perkalian antara skor $\mathrm{x}$ dan skor y

$\Sigma x \quad=$ jumlah total skor $\mathrm{x}$

$\Sigma y \quad=$ jumlah total skor $\mathrm{y}$

$\sum x^{2} \quad=$ jumlah dari kuadrat $\mathrm{x}$
$\Sigma y^{2} \quad=$ jumlah dari kuadrat $\mathrm{y}$

$(\Sigma x)^{2}=$ jumlah nilai $\mathrm{x}$ kemudian

dikuadratkan

$(\Sigma y)^{2}=$ jumlah nilai $\mathrm{y}$ kemudian dikuadratkan

2. Analisis reliabilitas

Reliabilitas menunjuk pada satu pengertian bahwa sesuatu instrumen cukup dapat dipercaya untuk digunakan sebagai alat pengumpul data karena instrumen tersebut sudah baik. Dalam penelitian ini untuk mengukur reliabilitas ditentukan dengan rumus Cronbach Alpha sebagai berikut (Arikunto, 2013).

$$
r_{11}=\left(\frac{n}{n-1}\right)\left(1-\frac{\Sigma \sigma_{i}^{2}}{\sigma_{t}^{2}}\right)
$$

Dengan:

$$
\sigma_{t}^{2}=\frac{\Sigma X^{2}-\frac{(\Sigma X)^{2}}{N}}{N}
$$

Keterangan:

$$
\begin{array}{ll}
r_{11} & =\text { indeks korelasi (harga reliabilitas) } \\
n & =\text { banyaknya butir soal } \\
\Sigma \sigma_{i}^{2} & =\text { jumlah varians butir. } \\
\sigma_{t}^{2} & =\text { varians total. } \\
N & =\text { banyak peserta yang mengisi angket } \\
X & =\text { skor yang diberikan }
\end{array}
$$

\section{Teknik Analisis Data}

\section{Analisis data kualitatif}

Teknik analisis data dalam penelitian kualitatif yang berupa observasi dan saran drai validator dilakukan secara deskriptif kualitatif.

a. Observasi

\section{Reduksi data}

Observasi dilakukan dengan cara mengumpulkan data secara langsung dengan menggunakan angket kebutuhan siswa yang terdiri dari 17 item pertanyaan, data yang didapat dari 17 item pertanyaain direduksi menjadi beberapa item pertanyaan yang sesuai dengan permasalahan penelitian yaitu pengembagan bahan ajar yang berupa modul elektronik. 


\section{Penyajian data}

Data yang telah direduksi disajikan dalam bentuk presentase dan dilihat seberapa besar tanggapan yang mendukung ataupun yang menolak akan pengembangan modul elektronik.

\section{Penarikan kesimpulan}

Berdasarkan data yang telah disajikan maka dapat ditarik kesimpulan bahwa responden menyetujui ataupun menolak akan pengembangan modul elektronik, data kualitatif pada tahapan ini disajikan dalam tahap potensi dan masalah.

b. Saran dari validator ahli media dan ahli materi

\section{Reduksi data}

Saran dari validator ahli media dan ahli materi ditulis terlebih dahulu dalam bentuk teks selanjutnya data yang berbentuk teks direduksi misalnya per indikator pada angket validasi ahli media dan ahli materi.

Penyajian data

Data yang telah direduksi selanjutnya disajikan dalam bentuk deskripsi, dari deskripsi tersebut maka dapat dilihat bahwa valaidator menyatakan layak atau belum layak modul elektronik dapat digunakan sebagai sumber belajar mandiri bagi siswa.

Penarikan kesimpulan

Setelah data disajikan maka ditarik kesimpulan bahwa validator menyatakan layak atau belum layak digunakan sebagai salah satu sumber belajar yang bisa digunakan oleh siswa, data kualitatif pada tahapan ini disajikan dalam tahap validasi desain.

2. Analisis data kuantitatif

Teknik analisis data dalam penelitian kuantitatif yang berupa skor validasi ahli media, validasi ahli materi dan persepsi siswa dilakukan secara statistik deskriptif dan disajikan dalam tabel. Langkah-langkah menganalisis data kuantitatif tersebut adalah sebagai berikut:

a. Mengkuantitatifkan hasil checking dengan memberi skor sesuai dengan bobot yang telah ditentukan sebelumnya.
Tabel 2. Interval Skala Likert

\begin{tabular}{cc}
\hline Respons & Bobot Skor \\
\hline Sangat Baik & 4 \\
Baik & 3 \\
Tidak Baik & 2 \\
Sangat Tidak Baik & 1 \\
\hline
\end{tabular}

(Sumber: Direktorat Pembinaan SMA, 2010)

b. Menentukan modus

Modus merupakan tekhnik penjelasan kelompok yang didasarkan atas nilai yang sedang popular (yang sedang menjadi mode) atau nilai yang sering muncul dalam kelompok tersebut.

c. Menentukan median

Median adalah salah satu teknik penjelasan kelompok yang didasarkan atas nilai tengah dari kelompok data yang telah disusun urutannya dari yang terkecil sampai yang terbesar, atau sebaliknya dari yang terbesar sampai yang terkecil.

d. Menentukan skor rata-rata indikator yang diberikan berdasarkan penilaian dari validasi ahli media, validasi ahli materi, dan persepsi siswa.

$$
\bar{X}=\frac{\sum X}{n}
$$

Keterangan:

$$
\begin{array}{ll}
\bar{X} & =\text { Mean } \\
\sum X & =\text { jumlah skor jawaban } \\
& \text { responden (validator) } \\
\mathrm{N} & =\text { jumlah responden }
\end{array}
$$

(validator)

e. Menentukan varians dan standar deviasi sampel.

$$
s^{2}=\frac{\sum(x i-\bar{x})^{2}}{(n-1)}
$$

$$
s=\sqrt{\frac{\sum(x i-\bar{x})^{2}}{(n-1)}}
$$

\section{Keterangan}

$s \quad=$ varians kelompok data

$s^{2} \quad=$ standar deviasi kelompok

$\mathrm{n} \quad=$ jumlah responden

(validator) 
f. Mengidentifikasi kecenderungan ubahan setiap sub variabel digunakan rata-rata ideal (Xi) dan standar deviasi ideal (SDi), dapat dihitung dengan acuan norma yaitu:

Xideal $=\frac{1}{2}$ (skor tertingi + skor terendah)

SDideal $=\frac{1}{6}$ (skor tertinggi - skor terendah)

g. Kemudian setiap sub variabel dikategorikan menjadi empat kategori dan diubah menjadi data kualitatif sebagai berikut :

Tabel 3. Rentang Skor dan Kriteria Kualitatif

\begin{tabular}{cc}
\hline Rentang Skor & Kriteria \\
\hline$X i+1,5 S D i \leq \bar{X} \leq X i+3,0 S D i$ & $\begin{array}{c}\text { Sangat } \\
\text { Baik }\end{array}$ \\
\hline$X i+0 S D i \leq \bar{X}<X i+1,5 S D i$ & Baik \\
\hline$X i-1,5 S D i \leq \bar{X}<X i+0 S D i$ & Tidak \\
& Baik \\
\hline$X i-3 S D i \leq \bar{X}<X i-1,5 S D i$ & Sangat \\
& tidak \\
& Baik
\end{tabular}

(Sumber: Direktorat Pembinaan SMA, 2010)

\section{Hasil dan Pembahasan}

Modul elektronik didesain dan dikembangkan berdasarkan hasil yang diperoleh dari tahapan observasi awal sampai pada tahapan desain. Untuk menyesuaikan apa yang dibutuhkan siswa dengan apa yang telah dikembangkan, maka dilakukan validasi sebanyak 2 kali. Validasi yang dilakukan yaitu validasi materi dan validasi media. Validasi dilakukan oleh 2 orang dosen Pendidikan Fisika Universitas Jambi. Validator akan memberikan saran, kritikan terhadap modul elektronik yang dikembangkan. Validasi dilakukan sampai validator menyatakan bahwa modul elektronik telah layak digunakan tanpa revisi.
1. Validasi Materi

Pada validasi materi tahap I, berdasarkan angket yang diberikan, validator menyarankan:

a. Menambahkan contoh soal yang sesuai dengan materi dan dapat mengukur kompetensi keberhasilan siswa.

b. Menyesuaikan gambar dengan materi

c. Menyesuaikan animasi dan video dengan materi.

Hasil validasi ahli materi tahap I dapat dilihat pada tabel 4 berikut.

Tabel 4. Validasi ahli materi tahap I

\begin{tabular}{ccc}
\hline Indikator & Skor & Ket. \\
\hline $\begin{array}{c}\text { Ketepatan } \\
\text { Materi dan Isi }\end{array}$ & 2 & Tidak Baik \\
$\begin{array}{c}\text { Kemuktahiran } \\
\text { Materi }\end{array}$ & 2 & Tidak Baik \\
Komponen & 2 & Tidak Baik \\
Kebahasaan & & \\
\hline
\end{tabular}

Setelah seluruh saran dari validator diperbaiki, maka pada validasi tahap kedua semua validator menyatakan modul elektronik telah layak dan dapat digunakan. Hasil validasi ahli materi tahap II dapat dilihat pada tabel 5 berikut.

Tabel 5. Validasi ahli materi tahap II

\begin{tabular}{ccc}
\hline Indikator & Skor & Ket. \\
\hline $\begin{array}{c}\text { Ketepatan } \\
\text { Materi dan Isi }\end{array}$ & 3,2 & Baik \\
\hline $\begin{array}{c}\text { Kemuktahiran } \\
\text { Materi }\end{array}$ & 3 & Baik \\
\hline $\begin{array}{c}\text { Komponen } \\
\text { Kebahasaan }\end{array}$ & 3 & Baik \\
\hline
\end{tabular}

2. Validasi Media

Pada validasi media tahap I, berdasarkan angket yang diberikan, validator menyarankan:

1. Menggunakan layout yang sesuai dengan judul dan materi yang digunakan.

2. Membuat layout yang sesuai dengan materi

3. Membuat layout kegiatan pembelajaran yang konsisten. 
4. Menggunakan gradasi warna yang pas.

5. Memperjelas tampilan gambar.

6. Mencari animasi dan video yang sesuai dengan materi.

7. Mengganti warna layout yang relevan.

8. Menggunakan warna yang transparan.

9. Tidak menggunakan tombol yang ketika ditampilkan di infokus jadi besar.

Hasil validasi ahli media tahap I dapat dilihat pada tabel 6 berikut.

Tabel 6. Validasi ahli media tahap I

\begin{tabular}{|c|c|c|}
\hline Indikator & Skor & Ket. \\
\hline Desain Sampul & 2 & Tidak \\
\hline Modul & & Baik \\
\hline Desain Isi & 2 & Tidak \\
\hline Modul & & Baik \\
\hline Desain Software & 2 & Tidak \\
\hline Modul & & Baik \\
\hline Komponen & 2 & Tidak \\
\hline Penyajian & & Baik \\
\hline Kemudahan & 2 & Tidak \\
\hline pengoperasian & & Baik \\
\hline Indikator & 2 & Tidak \\
\hline keseluruhan & & Baik \\
\hline
\end{tabular}

Setelah seluruh saran dari validator diperbaiki, maka pada validasi tahap kedua semua validator menyatakan modul elektronik telah layak dan dapat digunakan. Hasil validasi ahli media tahap II dapat dilihat pada tabel 7 berikut.

Tabel 7. Validasi ahli media tahap II

\begin{tabular}{ccc}
\hline Indikator & Skor & Ket. \\
\hline $\begin{array}{c}\text { Desain Sampul } \\
\text { Modul }\end{array}$ & 3 & Baik \\
$\begin{array}{c}\text { Desain Isi } \\
\text { Modul }\end{array}$ & 3 & Baik \\
$\begin{array}{c}\text { Desain Software } \\
\text { Modul }\end{array}$ & 3 & Baik \\
$\begin{array}{c}\text { Komponen } \\
\text { Penyajian }\end{array}$ & 3 & Baik \\
Kemudahan & 3 & Baik
\end{tabular}

\section{pengoperasian \\ Indikator \\ 3 \\ Baik \\ keseluruhan}

Setelah selesai divalidasi oleh dosen, tahap selanjutnya adalah melakukan uji coba modul elektronik pada siswa kelas XI IPA dan XII IPA SMAN 11 Muaro Jambi. Hasil uji coba pada siswa XII IPA digunakan untuk menentukan reliabilitas angket, sedangkan hasil uji coba siswa kelas XI IPA 1 digunakan untuk menentukan persepsi siswa terhadap modul elektronik yang dikembangkan. Uji reliabilitas dilakukan dengan menggunakan program SPSS dengan mengacu pada persamaan Alfa Cronbach, sehingga diperoleh nilai reliabilitas angket sebesar $r_{11}=0.850$ dengan kategori reliabilitas sangat tinggi. Dari perhitungan tersebut, dapat disimpulkan bahwa angket dapat dipercaya dan dapat digunakan untuk mengambil data terhadap kelayakan modul elektronik yang telah dikembangkan.

Setelah didapat nilai reliabilitas angket yang digunakan, kemudian dilakukan uji coba untuk melihat kelayakan modul elektronik. Uji coba dilakukan pada siswa kelas XI IPA, di mana data yang diambil adalah persepsi siswa terhadap modul elektronik yang telah dikembangkan. Angket yang digunakan terdiri dari 6 indikator penilaian yaitu desain sampul modul, desain isi modul, desain software modul, komponen penyajian ,kemudahan pengoperasian, dan komponen kebahasaan. Enam indikator ini terdiri dari 22 penyataan.

Berdasarkan angket persepsi siswa, didapatkan hasil persepsi siswa terhadap pengembangan modul elektronik sebagai berikut:

Tabel 8. Hasil persepsi siswa terhadap pengembangan modul elektronik

\begin{tabular}{ccc}
\hline Indikator & Skor & Ket. \\
\hline $\begin{array}{c}\text { Desain Sampul } \\
\text { Modul } \\
\text { Desain Isi } \\
\text { Modul }\end{array}$ & 56,25 & Baik \\
$\begin{array}{c}\text { Desain Software } \\
\text { Modul } \\
\text { Komponen } \\
\text { Penyajian }\end{array}$ & 57,46 & Baik \\
$\begin{array}{c}\text { Kemudahan } \\
\text { pengoperasian }\end{array}$ & 56,5 & Baik \\
& & Baik \\
& & Baik
\end{tabular}




\begin{tabular}{ccc}
$\begin{array}{c}\text { Komponen } \\
\text { Kebahasaan } \\
\text { Indikator } \\
\begin{array}{c}\text { keseluruhan } \\
\text { kelurik }\end{array}\end{array}$ & 55,3 & Baik \\
\hline
\end{tabular}

Berdasarkan tabel 7 dapat disimpulkan bahwa modul elektronik yang telah dikembangkan dikategorikan memiliki kelayakan yang baik. Hasil ini dihitung berdasarkan rumus yang di ambil dari jarak interval dengan menggunakan skala 4 .

Hal tersebut dapat dilihat dari skor yang didapatkan untuk indikator desain sampul modul dengan 4 pernyataan sebesar 56,25 dalam kategori sangat baik, indikator desain isi modul dengan 7 pernyataan sebesar 57,46 dalam kategori sangat baik, indikator desain software modul dengan 4 pernyataan sebesar 55,5 dalam kategori sangat baik, indikator komponen penyajian dengan 1 pernyataan sebesar 52 dalam kategori sangat baik, indikator kemudahan pengoperasian dengan 1 pernyataan sebesar 56 dalam kategori sangat baik, serta indikator komponen kebahasaan dengan 5 pernyataan sebesar 55,3 dalam kategori sangat baik, dan untuk hasil persepsi siswa secara keseluruhan dengan 22 indikator pernyataan sebesar 55,4 dalam kategori sangat baik.

\section{Spesifikasi}

1. Modul elektronik yang dibuat merupakan bahan ajar Fisika yang dikembangkan dengan menggunakan aplikasi $3 D$ PageFlip Profesional.

2. Format akhir dari modul elektronik ini yaitu dalam format exe.

3. Kerangka modul terdiri dari cover modul, peta kedudukan modul, kegiatan pembelajaran per sub bab dengan contoh dan latihan soal serta tes formatif akhir.

4. Materi momentum dan impuls disajikan secara mendalam yang dilengkapi dengan persamaan yang jelas, video, gambar, animasi, simulasi, contoh soal, dan soal latihan yang dapat membantu dalam proses pembelajaran

5. Kegiatan pembelajaran dalam modul elektronik menggunakan pendekatan siantifik

6. Tingkat pengguna aplikasi: SMA/MA Kelas XI

Keunggulan
Keunggulan yang terdapat pada modul elektronik yaitu:

1. Modul elektronik ditampilkan dalam bentuk tiga dimensi.

2. Kegiatan pembelajarn disusun agar siswa dapat mengkonstruksi konsep, hukum dan prinsip melalui tahapan pembelajaran.

3. Materi hukum termodinamika disusun secara mendalam yang dapat membantu siswa dalam proses pembelajaran.

4. Dapat menggunakan modul elektronik tanpa memiliki aplikasinya.

Kelemahan

Kelemahan yang terdapat pada modul elektronik yaitu:

1. Hanya terdapat satu simulasi yaitu pada kegiatan pembelajaran satu

2. Tidak ada video dan animasi dikegiatan pembelajaran tiga.

3. Belum bisa terkoneksi dengan internet.

4. Tidak bisa digunakan pada windows 7 kecuali ada Adobe Flash Player.

5. Belum bisa digunakan pada smartphone.

Kajian Produk Akhir

Adapun kajian produk akhir dari modul elektronik yang telah dikembangkan sebagai berikut:

1. Cover modul elektronik

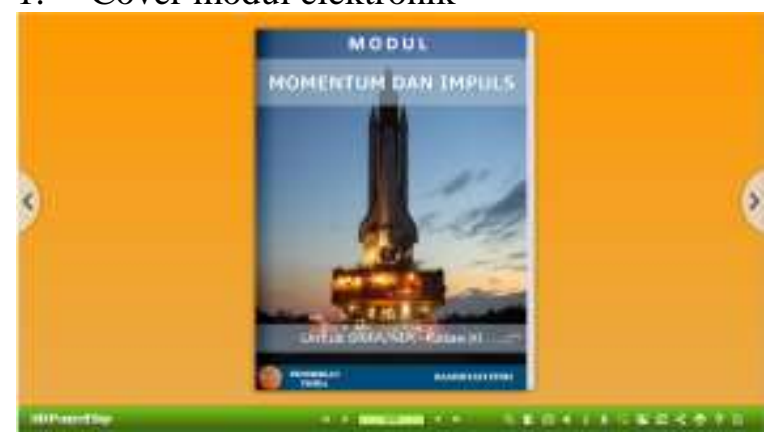

2. Profil penulis

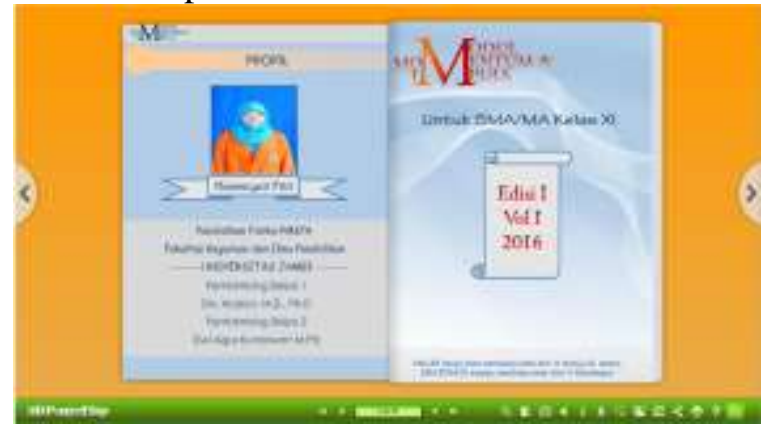


3. Kata pengantar modul elektronik

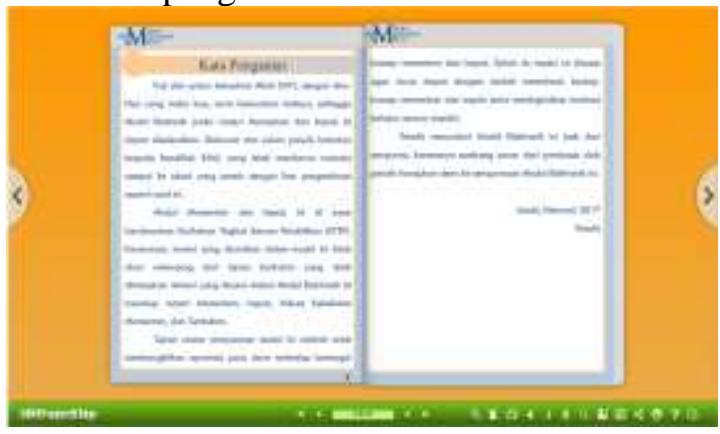

4. Daftar isi modul elektronik

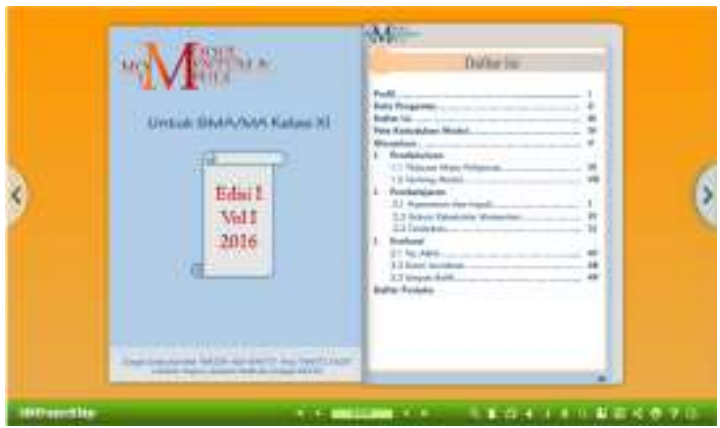

5. Peta kedudukan modul elektronik

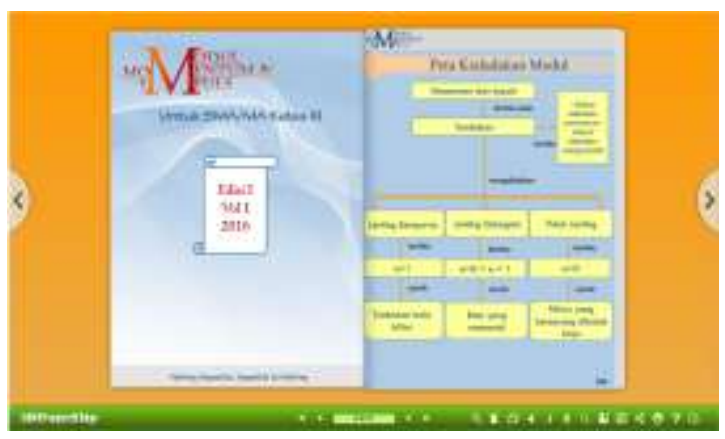

6. Pendahuluan modul elektronik

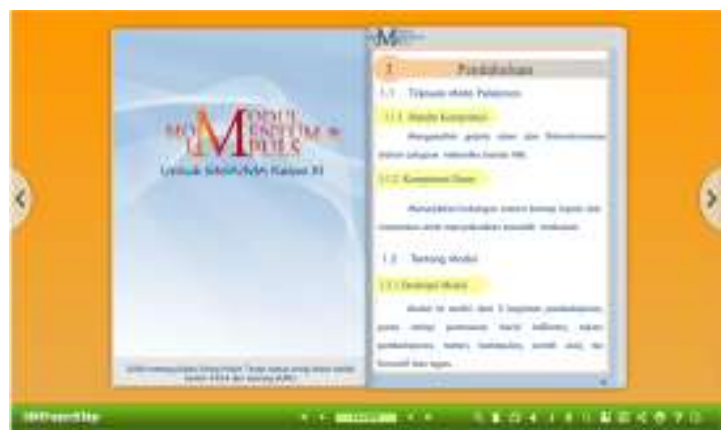

7. Petunjuk penggunaan modul elektronik

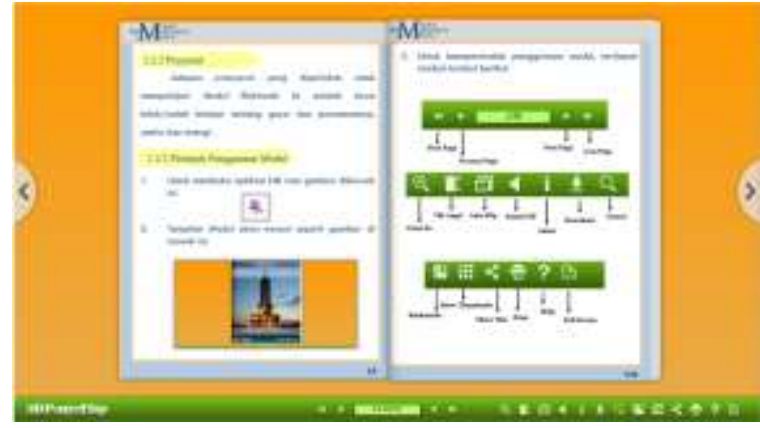

8. Bagian awal kegiatan pembelajaran

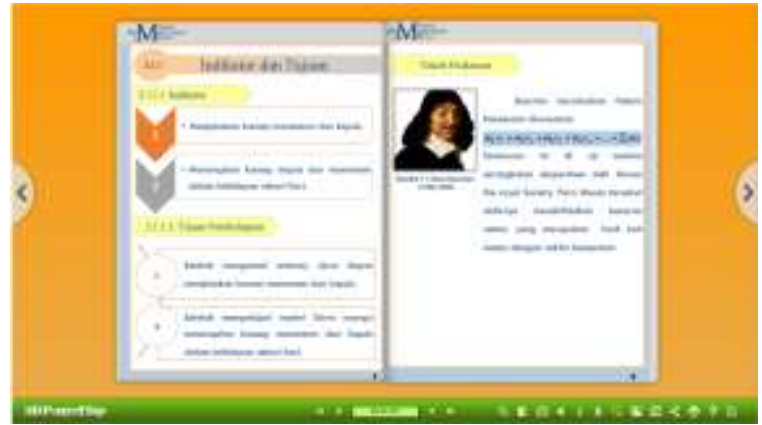

9. Tampilan materi pembelajaran

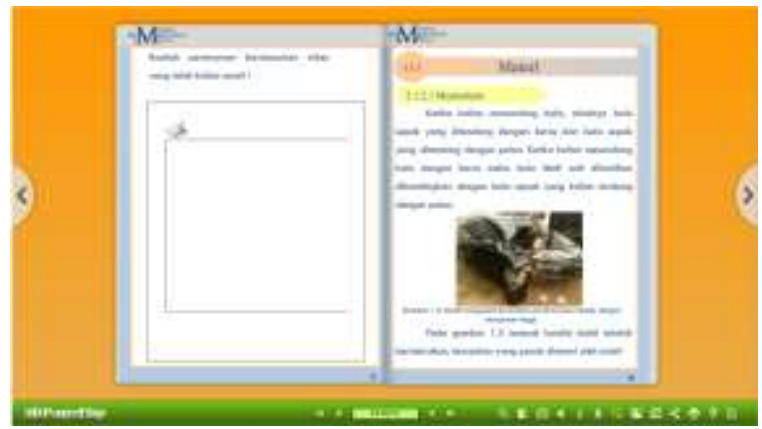

10. Rangkuman modul elektronik

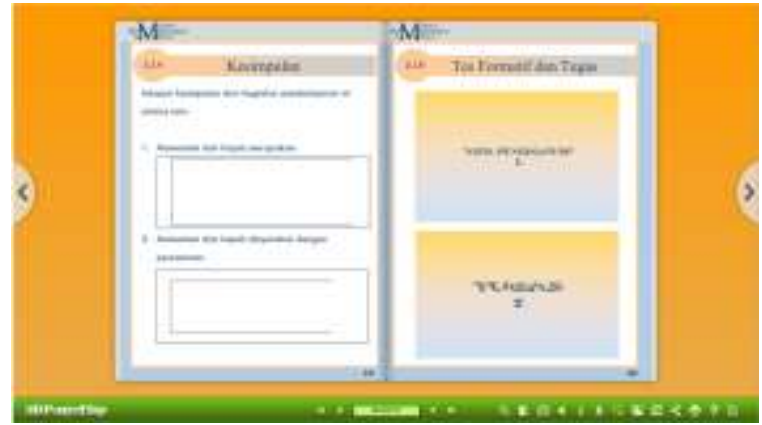


11. Tampilan contoh soal

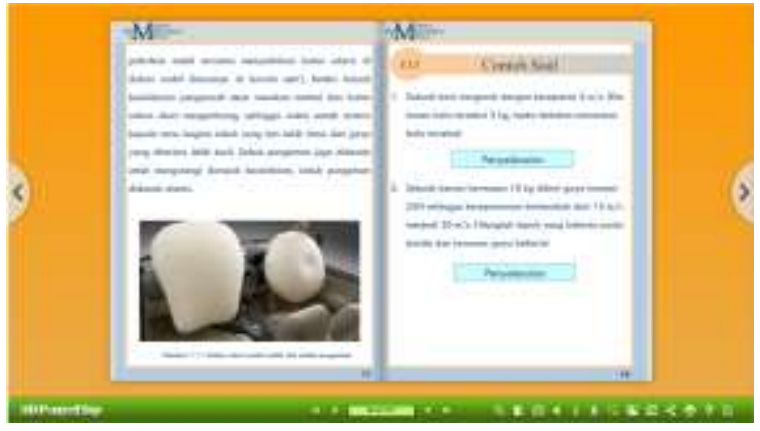

12. Tampilan tes formatif akhir

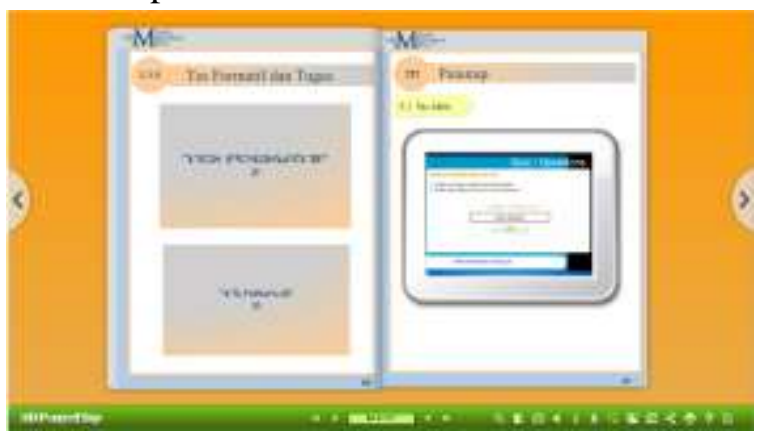

Simpulan dan Saran

Simpulan

Berdasarkan hasil pengembangan dan uji coba modul elektronik maka dihasilkan modul elektronik dengan pokok bahasan Momentum dan impuls untuk SMA kelas XI yang valid dan layak digunakan.dengan skor ahli materi sebesar 3,1 dan ahli media sebesar 3.68 yang termasuk dalam kategori baik. Produk yang dihasilkan memiliki spesifikasi antara lain software menggunakan $3 D$ PageFlip Professional, format akhir program .exe, kerangka modul tediri dari cover modul, peta kedudukan modul, kegiatan pembelajaran per sub bab dengan contoh dan latihan soal serta tes formatif akhir, materi disajikan dengan persamaan yang jelas, gambar, video, animasi, simulasi, contoh soal dan latihan soal. Adapun keunggulan yang terdapat pada modul elektronik yaitu modul ditampilkan dalam bentuk tiga dimensi, kegiatan pembelajaran disusun agar siswa dapat mengkonstruksi konsep, hukum atau prinsip melalui tahapan pembelajaran. Kelemahan pada modul elektronik yaitu hanya terdapat satu simulasi dikegiatan pembelajaran satu, tidak ada video dan animasi dikegiatan pembelajaran tiga, belum bisa terkoneksi dengan internet dan belum bisa digunakan pada smartphone Hasil persepsi siswa terhadap modul elektronik yaitu 55,4 dan dikategorikan sangat baik.

Saran

Berdasarkan

keterbatasan pengembangan yang diperoleh saat melakukan uji coba di lapangan, dapat disarankan beberapa hal sebagai berikut:

1. Peneliti tidak sampai mengembangkan ketahap implementasi, di harapkan kepada pengembangan selanjutnya meneliti sampai tahap implementasi.

2. Bagi siswa yang menggunakan e-modul, diharapkan mempelajari dengan teliti contoh soal yang disajikan dan agar dapat menjawab pertanyaan selanjutnya dan memudahkan dalam menemukan konsep dari materi.

3. E-modul yang dikembangkan Penulis memiliki beberapa keterbatasan yaitu masih sedikitnya animasi dan simulasi yang digunakan dan belum adanya petunjuk penggunaan simulasi yang digunakan.

4. Menambah lebih banyak animasi dan simulasi terhadap setiap kegiatan belajar dalam $e$-modul, sehingga lebih menambah pemahaman siswa terhadap materi.

5. Menyediakan petunjuk penggunaan animasi dan simulasi terhadap setiap animasi dan simulasi yang dimuat dalam e-modul, sehingga siswa lebih mudah dalam menggunakan setiap animasi dan simulasi yang ada.

\section{Daftar Pustaka}

Arikunto, Suharsimi. (2010). Prosedur penelitian (Suatu Pendekatan Praktik). Jakarta: Rineka Cipta

Borg, W.R; Gall, J.P., Gall, M.D.(2003). Educational Research. United States of America: Pearson Education

Daryanto. (2013) Menyusun Modul Bahan Ajar untuk Persiapan Guru dalam Mengajar. Yogyakarta: Gava Media. 
Djelita, R.D.P. Pemilihan dan Pengembangan Bahan Ajar Mata Pelajaran. E-Jurnal Dinas Pendidikan, 5: (2).

Erwinsyah. (2015). Pengembangan Modul Fisika Materi Momentum dan Impuls Berbasis Metakognisi untuk Siswa Kelas XI SMA PGRI Pandan Belitung. JRKPF, 2 (1):13-14

Ghaliyah, S., Bakri, F., Siswoyo. 2015. Pengembangan Modul Elektronik Berbasis Model Learning Cycle 7E Pada Pokok Bahasan Fluida Dinamik Untuk Siswa SMA Kelas XI. Prosiding Seminar Nasional Fisika. 4(4): 149154

Haryadi, B. (2009). Fisika 2 untuk SMA/MA Kelas XI. Jakarta: Pusat Perbukuan.

Masril. (2012). Pengembangan Model Pembelajaran Fisika SMA Berbasis Grafhic Organizers Melalui Belajar Kooperatif Tipe STAD. Jurnal Penelitian Pembelajaran Fisika,:3

Nurachmandani, S. (2009). Fisika 2 untuk SMA/MA Kelas XI. Jakarta: Pusat Perbukuan.

Nurmayanti, F., Bakri, F.,dan Budi, E.(2015). Pengembangan modul elektronik fisika dengan strategi PDEODE pada pokok bahasan teori kinetic gas untuk siswa kelas XI SMA.

Prastowo. A. 2013. Pengembangan Bahan Ajar Tematik Panduan Lengkap Aplikatif. Yogyakarta: Diva Press.

Purnamawati, H., Karyanto, P; Dwiastuti, S and Wulandari, D.S. (2015). Penerapan emodule berbasis problem-based learning untuk meningkatkan keterampilan proses sains dan mengurangi miskonsepsi peserta didik kelas $\quad \mathrm{x}$ mia 2 sma batik 1 surakarta,

Rahmawati. (2015). Penerapan Bahan Ajar Media Komik Pada Konsep Fotosintesis untuk Meningkatkan Hasil Belajar Peserta Didik di SMP Islam Dairul Ulum Banda Aceh. Jurnal EduBio Tropika, 3 (1): 34-35

Rufii, R. (2015). Developing Module on Constructivist Learning Strategies to
Promote Students' Independence and Performance. International Journal of Education, 7 (1): 19-20

Salsabila, R.P. (2013). Pengembangan Modul Elektronik Fisika sebagai Media Intruksional Pokok Bahasan Hukum Newton pada Pembelajaran Fisika di SMA Jurnal Pembelajaran Fisika, 1 (1): $12-19$

Sarwono. (2009). Fisika 2 Mudah dan Sederhana. Jakarta: Pusat Perbukuan.

Suarsana, I M; Mahayukti G.M. (2013). Pengembangan E-modul Berorientasi Pemecahan Masalah Untuk Meningkatkan Keterampilan Berfikir Kritis Mahasiswa. Jurnal Pendidikan Indonesia, 2(2): 266-26

Sugianto, Dony dkk, (2013). M|odul Virtual Multimedia FlipBook Dasar Teknologi Digital. Jurnal INVOTEC, 9(2): 110-116

Sugiyono. (2013). Metode Penelitian Pendidikan Pendekatan

Kuantitatif. Kualitatif, dan $R \& D$. Bandung: Alfabeta

Suryosubroto, B. (1983). Sistem Pengajaran dengan Modul. Yogyakarta: PT Bina Aksara.

Widoyoko, S.E.P. 2014. Teknik Penyusunan Instrumen Penelitian. Yogyakarta: Pustaka Pelajar.

Wijayanto., Zuhri ., M.S. (2014). Pengembangan e- modul berbasis flip book maker dengan model project based learning untuk mengembangkan kemampuan pemecahan masalah matematika,

www.3D-PageFlip.com. Diakses tanggal 1 November 2015. 